\title{
Workplace Skills in Technical Education as a Catalyst for Producing Employable Graduates in the $21^{\text {st }}$ Century
}

\author{
Dr. (Mrs.) Jane Itohan Oviawe ${ }^{1}$, Dr. Adeola Lukmon ${ }^{2}$ \\ ${ }^{1}$ (Department of Vocational and Technical Education Ambrose Alli University, Ekpoma, Edo State, Nigeria \\ ${ }^{2}$ Provost, Tai Solarin College of Education, Oти Ijebu, Ogun State, Nigeria
}

\begin{abstract}
The $21^{\text {st }}$ century workplace demands a set of workplace skills for employability which the employers complain as lacking in most Nigerian graduates. It is no longer news that there exist a discrepancy between the expectations of employers of labour and those of most Nigerian graduates regarding the skills required for employment. The need therefore arises for workplace skills to be integrated into technical education programme. It is against this background, that this paper highlighted and discussed the concept of Technical education in Nigeria, concept of workplace skills, its importance and forms of workplace skills, the need for workplace skills in technical education programme, the need for change of teaching methods in technical education, factors influencing development of workplace skills, and approaches for implementing workplace skills in technical education programmes. This paper concludes that possessing workplace skills by graduates in Technical Education programmes will be a ticket for employment in the $21^{\text {st }}$ century workplace. This paper suggests among others that educational institutions offering technical education programmes and stakeholders should include workplace skills and attributes required in the $21^{\text {st }}$ century workplace in technical education curriculum; and collaborate strongly with employers/organizations and industries to design technical education curriculum looking at the needs of the $21^{\text {st }}$ century world of work.
\end{abstract}

Keywords: $21^{\text {st }}$ century, technical education, workplace skills

\section{Introduction}

Technology is dynamic. With technological development and advancement, the world of work is in a constant state of flux and change. The rapid advancement in technological development has placed new demands for the $21^{\text {st }}$ century workforce which products of technical education are prepared to serve. The $21^{\text {st }}$ century workforce is unique where only people with adequate skills can serve. The unique characteristics of the $21^{\text {st }}$ century according to Aguba (2012) are:

i. a scientific and computer world;

ii. a technological or jet age demanding efficient use of the computer in all spheres of life;

iii. an age requiring sound scientific and technological skills for children to cope with its complexity;

iv. a world where emphasis will be more on accuracy, competence, efficiency and effectiveness which are derived from educational foundation; and

v. an era of highly skilled practitioners are generalists.

These unique characteristics have made employers of labour to find graduates unusable in the world of work. Equipping Nigerian youths and school leavers with technical and vocational skills for personal fulfillment and production of goods and services is no longer enough but linked with workplace skills to be literate and knowing how to use specific applications may help people secure suitable employment and foster employment. Obviously, the $21^{\text {st }}$ century workplace needs the services of global workers who can adapt to the changes in technology in the world of work. Thus, greater emphasis should be placed on providing students with broad learning and problem-solving skills in order to prepare them for a wide range of challenges posed by technological advancement (Szczurkwska, 1997). According to Ogwo (2005), with technological advancement and globalization in workplaces, employers are seeking employees who are able to flexibly acquire, adapt, apply and transfer their knowledge to different contexts and under varying technological conditions and to respond independently and creatively. The current trend of globalization has brought with it series of demands in employee skills in order to be able to meet with the needs of the $21^{\text {st }}$ century workplace. Shafe \& Nayan (2010) stated that employers the world-over require highly trained employees with academic, technical and employability skills in order to meet the demands of the ever changing world of technology, global competition and increasing social universe. Employers need their workforce to work readily and confidently across worldwide operations, using a global outlook to consider new opportunities and challenges (Barnett, 2011). He added that employers need employees who can assimilate organizational values and operate comfortably with the technological and cultural demands of the $21^{\text {st }}$ century workplace. A sure way of addressing this challenge is through the development of workplace skills in schools. This implies that employees with workplace skills set 
and knowledge will benefit from integration into the $21^{\text {st }}$ century workplace. It becomes imperative therefore, that for Nigeria to move with the current trend of things and compete globally, her citizens, in schools and those out of school, need to have competencies and capabilities to be able to work across national borders, manage complex international and intercultural relationships and understand global aspects of the world of work. It is against this background that this paper focused on the integration of workplace skills in technical education to foster the production of employable graduates for sustainable development.

\section{Concept of Technical Education in Nigeria}

Technical education involves the study of techniques, related sciences, acquisition of practical skills, attitudes and knowledge relating to occupational sector and economic life. The primary aim of technical education is to equip its recipients with manipulative skills for gainful employment. Technical education is a formidable force that will imbue the individual with appropriate skills, knowledge, abilities and competencies that will enable the person become self-employed and self-reliant towards sustainable economic development. It is the education that is designed technically and systematically to accommodate both the trainer and the trainee to enable the trainee acquire the basic knowledge, skills, abilities, understanding and attitudes needed foe ones efficient performance in his or her chosen occupational career for self-reliance and national development. It is the education that deals with the acquisition of knowledge, skills, understanding and attitude to perform effectively in the world of work. The objectives of technology education as stated by FRN (2013) are:

i. provide courses of instruction and training in engineering, other technologies, applied science, business and management, leading to the production of trained manpower;

ii. provide the technical knowledge and skills necessary for agricultural, industrial, commercial, and economic development of Nigeria;

iii. give training that impart the necessary skills for the production of technicians, technologists and other skilled personnel who shall be enterprising and self-reliant;

iv. train people who can apply scientific knowledge to solve environmental problems for the convenience of man; and

v. give exposure on professional studies in the technologies.

As laudable as these objectives are, Technical education programmes cannot currently meet the desired needs or requirements of the $21^{\text {st }}$ century workplace unless it complies with the current trend of the application of workplace skills.

\section{Concept of Workplace Skills}

Workplace skills are those basic skills necessary for getting, keeping, and doing well on a job. Workplace skills are foundation skills that apply across the board, no matter what the specific job may be. These are skills given utmost importance in job interviews and in the world of work, and are required not only to gain employment, but also to progress within an enterprise so as to achieve one's potentials and contribute successfully to enterprise strategic directions. They are also sometimes referred to as generic, employability or soft skills, capabilities or key competencies (Australian Chamber of Commerce and Industry \& Business Council of Australia 2002). Workplace skills include thinking skills such as logical and analytical reasoning, problem solving and intellectual curiosity; effective communication skills, teamwork skills and capability to identify, access and manage knowledge and information, personal attributes such as imagination, creativity and intellectual rigour and values such as ethical practice, persistence, integrity and tolerance (Hager, Holland \& Beckett 2002). Workplace skills are important because jobs today require flexibility, initiative and the ability to undertake many different tasks. They are not as narrowly prescribed and defined as in the past and generally they are more service oriented, making information and social skills increasingly important (Australian Chamber of Commerce and Industry and Business Council of Australia, 2002).

\subsection{Forms of Workplace Skills}

Workplace skills are generally divided into three skill sets: basic academic skills; higher-order thinking skills; and personal qualities (Ottawa: The Conference Board of Canada, 2000). According to Confederation of British Industry (1998), workplace skills are those relevant to a person's learning, career and to personal life, with a strong emphasis on their application to employability. They are: communication, numeracy or the application of numbers; use of information technology; adaptability; career management; commitment to lifelong learning.

Employability skills necessary for getting, keeping, and doing well on a job include: reading, writing, science, mathematics, oral communication, listening, learning, reasoning, thinking creatively, decision making, problem solving, responsible, self confidence, self control, social skills, honest, have integrity, adaptable and flexible, team spirit, punctual and efficient, self directed, good work attitude, well groomed, cooperative, self 
motivated, and self management. According to The Conference Board of Canada (2000), Employability Skills includes:

i. fundamental skills (communicate, manage information, use numbers, think/solve problems);

ii. personal management skills (demonstrate positive attitudes and behaviours, be responsible, be adaptable, learn continuously, work safely);

iii. teamwork skills (work with others, participate in projects and tasks); and

iv. an orientation to values and attitudes with references to self-esteem, integrity, responsibility.

O'Neil, Allred \& Baker (1997) asserted that the common elements are of generic skills: basic/foundation skills (literacy, numeracy, communication); higher order thinking skills (adapting to change, problem-solving, creativity, decision-making, learning how to learn); interpersonal and team skills (communication, co-operation, negotiation/conflict resolution, leadership, and dealing with diversity); and personal characteristics and attitudes (including politeness, perseverance, goal-setting, positive self-worth).

Saravanan (2009) classified soft skills into communicative skills; critical thinking and problem Solving skills; team work; long learning and information management skills; entrepreneurship skills; ethics, moral and professional; and leadership skills (Saravanan, 2009). The following are sub-skills of each workplace skill:

3.1.1 Communication Skills. Has to do with the ability to: deliver ideas clearly, effectively and with confidence either orally or in writing; practice active listening skills and response; and present clearly and confidently to the audience.

3.1.2 Critical Thinking. The sub-skills under this category are: ability to identify and analyze problems in difficult situation and make justifiable evaluation; ability to expand and improve thinking skills such as explanation, analysis and evaluate discussion; ability to find ideas and look for alternative solutions; and ability to build a good rapport, interact and work effectively with others.

3.1.3 Teamwork. This is a workplace skill which is indispensable for technical education graduates who would like to work in industries. The sub-skills of Teamwork are: ability to understand and play the role of a leader and follower alternatively; and ability to recognize and respect others attitude, behaviour and beliefs. Teamwork involves working confidently within a group, contributing your own ideas effectively, taking a share of the responsibility, being assertive - rather than passive or aggressive, accepting and learning from constructive criticism and giving positive, constructive feedback to others.

\section{The Need for Workplace Skills in Technical Education}

Despite the laudable objectives of technical education, Professor Charles Soludo lamented that Nigerians are not employable due to poor standard of education. He added that about 60 percent of graduates being produced from Nigerian tertiary institutions were not qualified for employment at the global level. He further asserted that the then President of Nigeria Alhaji Umaru Musa Yar'Adua commented that millions of graduates from Nigerian educational institutions of higher learning in the labour market are not qualified to be employed. He reported that Sam Egwu the then Minister of education also stated that 80 percent of the country's graduates are unemployable thus only 20 percent of the graduates are employable. According to Ocho (2010), a look at Nigerian newspapers and other news media, gives one the impression that the values for societal survival and growth through education are non-existent in the country.

Reviewing of the employers of labour's report, Nwaoku \& Tom (2009) posited that employers of labour complained about fall in the standard of tertiary education over the past decades. They added that a university degree is no longer a guarantee to effective communication skills and technical competences. They suggested that educational institutions should make their curriculum relevant to the present society.

Turner (2002) listed sub-skills necessary for employability. These include ability to deliver ideas clearly, effectively and with confidence either orally or in writing; practice active listening skills and response; ability to present clearly and confidently to the audience; reason; expand and improve thinking skills such as explanation, analysis and evaluate discussion; ability to build a good rapport, interact and work effectively with others; identify and analyze problems in difficult situations and make justifiable evaluation; and expand and improve thinking skills such as explanation, analysis and evaluate discussion.

Apart from imparting technological knowledge input, technical education institutions will have to focus on nurturing the employability skills so that they can empower the talent pools. The real challenge before educational institutions is positioning themselves as neutral ambassadors in providing necessary inputs on the employability of the students, through scientifically designed curriculum and assessments, to meet the demands of the multi-national companies in today's scenario (Ratio Pty Ltd \& Down, 2002). Naturally, the technical education programme will have to perform the role of a trainer apart from teaching. The syllabus has to be designed to enhance the employability skills of individual candidates and help them to get placement in MultiNational Companies. 
Workplace skills training has to be incorporated in the curriculum and it should be spread over the entire period of the technical education programme. This will enhance the students' performance. Initially it would be more challenging but it would be liked by the learners. This will bring in lot more changes in the learning as well as the teaching. The entire teaching should be learner-centered approach rather than teachercentered. The industry people do not want to spend their time on soft skills training again. Instead, they expect to receive the candidates who are industry ready. In such a case, the necessary changes are needed to be made in the teaching methodology and curriculum, so as to meet the expectations of the $21^{\text {st }}$ century workplace. A lot of time and money spent by the employers can be saved by introducing necessary changes in the curriculum teaching methodology.

Ratio Pty Ltd \& Down (2002) suggested the need to develop and nurture a new understanding of generic competencies. Employers would welcome this. They have been singing out for people with good generic skills for a long time. Employers are keen on education programs that develop problem-solving and enterprising skills, teamwork and communication skills, and self management, planning and organizing and learning skills, as well as specific technical knowledge and skills. This has raised the need for technical education to develop a good understanding of these skills and how to build their development into teaching and learning processes. These skills underpin success in gaining and progressing in employment and life generally. They are used in combination in an interlocking and overlapping manner to perform work tasks. They are the transferable skills needed for unpredictable working careers.

\section{The Need for Change of Teaching Methods in Technical Education Programmes}

Most of the methods, namely: demonstration method, lecture method, discussion method, project method and field trip method predominantly used by the technical teachers are based on behavioural learning theories. According to Boyle, Duffy \& Dunleavy (2003), these methods emphasize knowledge transmission from the teacher to passive students; encourage rote memorization of facts. In the same vein, UNESCO (2002) reported that in the traditional teacher-centred approach of learning, the teacher is the expert and the dispenser of 'broadcast' model of learning where the teacher serves as the repository and transmitter of knowledge to the students. The traditional paradigm according to UNESCO is often characterized by the following view of learning:

5.1 Learning is based on a deficit model of the student: The teacher strives to identify deficiencies and weaknesses of the student. Based on noted deficiencies, students are tracked, categorized, remediated or failed. The impact of the deficit model of student learning is most obvious in compensatory education programmes. As applied by the term, compensatory education is designed to make up or remediate learning that some children particularly poor minority children, do not have, but which the curriculum and structure of schooling assume are common to all children.

5.2 Learning is a process of information transfer and reception: Much of our present learning enterprise remains "information-oriented" emphasizing students reproducing knowledge rather than producing their own knowledge. It also remains teacher-centred. Many still see the role of the teacher as a dispenser of information and the role of the student as a passive receiver, storer and repeater of the transmitted information. The prevalence of this view is supported by observations that teachers continue to rely on old standbys such as lectures, textbooks reading, and fill-in-the-worksheets practices that reduce students to passive recipients of information and fail to develop their thinking skills.

5.3 Learning is an individual/solitary process: In a study of schools in the United States, the National Assessment of Educational Progress noted most students spend long hours working alone at their desks completing worksheets or repetitive tasks. A London Times survey of English school children revealed that students almost unanimously rejected this daily ordeal of dull and ritualistically solitary classroom activity and called for a broader and more exciting curriculum. Above all, they wanted more work allowing them to think for themselves. They wanted to design and make things, to experiment and to engage in first-hand observation. The Times reported however, that there was little evidence of changes in the curriculum that would respond to the students' wishes.

5.4 Learning is facilitated by breaking content/instruction into small isolated units: The educational system is often geared more to categorizing and analyzing patches of knowledge than to sewing them together.

5.5 Learning is a linear process: Frequently, the textbook or teacher provides only one linear path through a narrow bounded content area or sequence of standardized instructional units.

The consequence of the traditional method of teaching is that students are unable to retain their learning and to apply it to new situations (Roegge, Wenting \& Bragg, 1996). However, the world of work nowadays is a world of technology (Olaitan, 1996). With respect to changes in the world of work, Hobart (1997) reported that not only has technology imparted extensively upon the knowledge and skills needed for employment, but, even more significantly, the precarious nature of employment, and the extent of unemployment with no available work; these have profound effect on the type of technical educational 
programme that need to be offered, and the teaching/leaning strategies that need to be employed. Ogwo (2005) commented on the implication of technological advancement in work places and demands of manpower noted that employers nowadays are seeking employees who are able to flexibly acquire, adapt, apply and transfer their knowledge to different conditions and to respond independently and creatively.

The challenge to equip students in technical education with the workplace basic skills required for $21^{\text {st }}$ century therefore necessitates a shift from the behavioural learning theories to those rooted in social interdependency learning theories (Karen, 2002). UNESCO (2002) maintained that a shift from teacher-centred instruction to learner-centred instruction is needed to enable students to acquire the new $21^{\text {st }}$ century knowledge and skills. In view of this, UNESCO reported that in contrast to the traditional teaching and learning paradigm, a new paradigm of teaching and learning process emerging based on three decades of research in human learning that encompasses the following views of the human learning process:

5.6 Learning is a natural process: The natural state of the brain is to learn, however, not everyone learns the same way. There are different learning, perceptual and personality styles that must be considered in the design of learning experiences for the individual student. Given interesting and rich learning environments, and supportive and stimulating teachers, students will learn. Teachers have often noted that children who appear disruptive or to have short attention spans when confronted with typical classroom instruction, may spend long periods engaged in meaningful and interesting computer-related activities.

5.7 Learning is a social process: The communal context of learning is beginning to be rediscovered, as evidenced by the rapid growth of quality circles and computer-supported collaborative works in business, government, medicine, and higher education, students learn best in collaboration with peers, teachers, parents, and others when they are actively engaged in meaningful, interesting tasks. Information Communication Technology provides opportunities for teachers and students to collaborate with others across the country and across the globe. They also provide new tools to support this collaborative learning in the classroom and on-line.

5.8 Learning is an active and not a passive process: In most fields, people are faced with the challenge of producing knowledge rather than simply reproducing knowledge. To allow students to move toward competence, they must be actively engaged in the learning process, in activities such as solving real problems, producing original writing, completing scientific research projects (rather than simply studying about science), dialoguing with others on important issues, providing artistic and musical performances, and constructing physical objects. The traditional curriculum asks students only to recall and describe what others have accomplished or produced. While all production of knowledge must be based on an understanding of prior knowledge, the mere reproduction of knowledge, without its connection to the production of knowledge is largely a passive activity that neither fully engages nor challenges students.

5.9 Learning may either be linear or non-linear: Much of what now happens in schools appears based on the notion that the mind works like a serial processor that is designed to process only one piece of information at a time in sequential order. But the mind is a wonderful parallel processor that may attend to and process many different types of information simultaneously. Cognitive theory and research sees learning as a reorganization of knowledge structures. The knowledge structures are stored in semantic memory as schema or cognitive maps, many of which overlap or are interconnected through a complex network of associations. There are many ways that students may acquire and process information and assimilate it into their existing knowledge structures. Although, some knowledge domains such as mathematics may perhaps lend themselves to a linear approach, not all learning can or should occur linearly.

5.10Learning is integrative and contextualized: Pribram's holistic brain theory suggests that information presented globally is more easily assimilated than information presented only in a sequence of information. It is easier for students to see relations and to make connections.

5.11Learning is based on a strength model of student abilities, interest, and culture: Based on the work of Howard Gardner and others, schools are beginning to consider the specific strengths and interests that students bring to the learning environment, and are designing learning activities that build on students' strengths rather than focusing only upon remediating weaknesses. In addition, schools increasingly recognize diversity as a resource rather than a problem in the classroom. In contrast to the remedial and standardized concept of instruction, diversity and individual differences are valued and the learning process is designed to build on the strengths and assets brought by the learner to the classroom.

5.12Learning is assessed through task completion, products and real problem solving of both individual and group efforts: Rather than simply evaluating students through paper and pencil tests, assessment are made using portfolios of actual performances and work in both collaborative and individual learning tasks. 


\section{Factors influencing Development of Workplace Skills}

The importance of developing workplace skills among technical education students cannot be over emphasized. To this end, Crebert (2006) in Oviawe (2010) asserted that graduate skills have become increasingly important over the past decade as graduates enter a workforce that is in more flexible, insecure and technology-dependent than ever before. According to Smith and Kruger (2008), the factors influencing the development of workplace skills are external and internal.

6.1 External trends and development include: strong competition in the labour market; large diverse graduate supply from higher education; a 'consumerism' attitude of graduates view about jobs/careers; improvements in graduate employability; employer concerns about the quality of higher education output; greater use of information technology in recruitment processes; and changing business practices and jobs roles.

6.2 Internal factors are: changes in people-management policies; renewed interest in developing leadership skills in graduates; less career hierarchical structures and more self managed careers; changing career philosophies; structural and organizational changes (globalization and new technologies); changes in the way learning is viewed and encouraged in organizations; and collaborative environments characterized by teamwork and leadership.

\section{Approaches for Implementing Workplace Skills in Technical Education}

It is a truism now that a strong disciplinary knowledge base (degree in specific area of study) does not guarantee graduates jobs rather graduate's attributes are seen as the variable that determines success in the workplace. Educational institutions offering technical education are challenged to look more closely at aligning classroom teachings with the needs of the $21^{\text {st }}$ century workplace. According to Ottawa: The Conference Board of Canada (2000), Workplace skills are teachable skills through: (i) Stand Alone Subject Model and (ii) Embedded Model.

7.1 Stand Alone Subject Model offers specific courses and elective courses to develop soft skills. In this model, students are encouraged to take additional courses, which are in no way related to the main courses. For example, a student who is pursuing Engineering or Building Technology course is encouraged to take additional courses like 'Management' and 'Mass Communication'. However, such an approach will require an increase in the number of credits and time spent for the particular programme (The Conference Board of Canada, 2000).

7.2 Embedded Model incorporates the workplace skills in the teaching and learning activities across the curriculum. This model does not require students to choose additional courses because workplace skills become the part of the learning outcomes of the respective courses. It includes activities like questioning, class discussion, brain storming, team work, presentation, role play, project, field work and site visits. However, this model is a challenging one as the teachers have to master specific teaching and learning skills and then apply these skills in the respective courses for the specific programme. Moreover, this model is based on student centered learning and it focuses on experimental learning, and problem-based learning. Besides it gives students the practical experience. Some of the appropriate strategies and methods that are practical include: learning by questioning; cooperative learning; problem-based learning (PBL); and elearning (The Conference Board of Canada, 2000).

Bowman (2009) asserted that active learning strategies, which include real and simulated work settings, cooperative learning, project-based activities and role plays, are the most effective for employability skills development. Bowman added that students respond very well to the introduction of more activity-based learning. The educational experience is more interesting, the jobs for which learners are heading are brought alive and motivation for learning is raised, and engagement with Technical Education improved. Activity-based learning in more detail involves the use of four adult learning principles to progress all of the employability skills:

i. Responsible learning or self directed learning and working independently to develop new knowledge and activities;

ii. Experiential learning or 'learning to do' and 'learning from doing' in real or simulated realistic contexts; and

iii. Cooperative learning or learning from each other and a range of people including colleagues, mentors, coaches, supervisors, trainers, and others (Bowman, 2009).

7.3 School and Workplace Collaboration: Today, the current reality of education is that there should be contact and interaction between technical education programme administrators and employers of labour. The school and the workplace should team up in partnership in practical ways to respond to the needs of the $21^{\text {st }}$ century workplace. This partnership should include assessing the technical education curriculum in order to meet the needs of the world of work. Once this assessment of curriculum has been done and the needs of the workplace are identified, technical education curriculum development can include the modification of 
existing course, the development of new course offerings and the sequential grouping of these courses to meet targeted goals (Barnett, 2011).

7.4 Curriculum adaptation to the needs of the Workplace: Technical education curriculum could be tied closely to the private sector through its partnership and its students will benefit from studying with people who are not only academics but are also actively working in the field of study and have direct contact and experience with the workplace. The people are best able to decide what skills and knowledge students' will meet in the $21^{\text {st }}$ century workplace and can constantly adapt course content and classroom discussion to the real needs of the students.

7.5 Internship/Workshop learning: The primary aim of technical education programme is to prepare its recipients with manipulative skills for gainful employment and contribute meaningfully to the economic and technological development of the society. This can be achieved through partnership between the school and the workplace to foster students' internship activities and programmes. Internship represents a legitimate and preferred method of giving experience which cannot be typically gained in the classroom setting and is valued by employers over all other methods of assessment for ensuring that graduates have the skills to be effective (Malerrich, 2009 in in Oviawe (2010). Malerich added that internships are very useful especially for graduates seeking for their first opportunity in workplace; and a perfect solution for gaining experience in the practical application of skills as well as building the global or intercultural competencies seemingly desired by employers across industry types and fields.

7.6 Integrated and contextualized learning: According to Shafie \& Nayan (2010), workplace skills are best learned when they are included among instructional goals and explicitly taught. These instructional goals should reflect the full range of academic, technical and employability skills. They further stated that in school settings, employability skills are best learned when classroom replicate key features of real work settings and students tasks approximate those performed by workers in those settings. The emphasis here is on contextualized learning rather than abstract learning in unrealistic classroom settings. In technical education, teaching and learning ought to be in workshops and classroom arrangement similar to that in the world of work. OFTSED (2007) asserted that the most suitable methods of learning workplace skills include: learning by doing, experimental learning, e-learning (virtual learning), video conferencing, group work, role playing and class discussion to facilitate exploration of ideas and deeper understanding.

\section{Conclusions and Suggestions}

Despite the variations in the nomenclature of workplace skills, there is a wide-ranging understanding of the qualities, characteristics, skills and knowledge that represent employability in general and for school leavers in particular. Graduates are expected to possess technical and academic skills and competencies; and also demonstrate a range of broader skills and attributes that include: communication, critical thinking, team working, problem-solving and managerial abilities among others required in the $21^{\text {st }}$ century workplace. Based on the importance of workplace as discussed in this paper, the following suggestions are made:

1. Educational institutions offering technical education programmes and stakeholder should include workplace skills and attributes required in the $21^{\text {st }}$ century workplace in technical education curriculum.

2. Educational institutions should collaborate strongly with employers/organizations and industries to design technical education curriculum looking at the needs of the $21^{\text {st }}$ century world of work.

3. Government at all levels should adequately fund technical education by providing the needed tools, equipment and facilities similar to those used in the $21^{\text {st }}$ century workplace in order for students to acquire appropriate skills, knowledge, attitudes and competencies for employability.

4. Educational institutions should form a strong working partnership with employers, organizations and industries to ease the transmission of workplace skills.

\section{References}

[1]. Aguba, C.R. (2012). Managing education in Nigeria through information and communication technology (ICT): Gains, threat and the way forward. Lead paper presented at the Association for encouraging quality education in Nigeria (ASSRQEN), held at Ebonyi State University, Abakiliki.

[2]. Szczurkwaska, A. (1997). The influence of technological development in automobile. Research in Science Education 65 (6), 105 115 .

[3]. Ogwo, B.A. Effects of meta-learning instructional strategies on students' achievement in metalwork technology. Unpublished Ph.D Thesis, Department of Vocational Teacher Education, University of Nigeria, Nsukka. 2005

[4]. Shafie, L.A. \& Nayan, S. (2010). Employability awareness among Malaysian undergraduates. International journal of business and management. 5(8), 119-123.

[5]. Barnett, D. (2011). Partnering industry and education for curricular enhancement: A response for greater educational achievement. Online Journal of Workforce Education and development 5 (2).

[6]. Australian Chamber of Commerce and Industry \& Business Council of Australia (2002). Employability skills for the future, Department of Education, Science and Training, Canberra. 
[7]. Hager, P., Holland, S., \& Beckett, D. (2002). Enhancing the learning and employability of graduates: The role of generic skills. The Business/Higher Education Round Table, Melbourne.

[8]. Conference Board of Canada (2000). Employability skills 2000+. Conference Board of Canada. Retrieved $29^{\text {th }}$ June, 2009 from http://www.conferenceboard.ca/nbec/pdf/esp2000.pdf.

[9]. O’Neil, H.F., Allred, K., \& Baker, E. (1997). Review of workforce readiness theoretical frameworks. In: Workforce readiness: Competencies and assessments. O’Neil, H.F. (ed.) New Jersey: Erblaum Associates.

[10]. Saravanan, V. (2009). Sustainable employability skills for engineering professionals. The Indian Review of World Literature in English 5 (II), $1-8$.

[11]. Ocho, L.O. (2010). Professor Benneth Ukeje memorial lectures. A paper presented at the annual conference of the Faculty of Education, Nnamdi Azikiwe University, Awka

[12]. Nwaoku, N.A., \& Tom, A. (2009). Nigeria's tertiary education curriculum in the $21^{\text {st }}$ century: The implications and challenges. Journal of curriculum organization of Nigeria. 3 (1\&2), 5-12.

[13]. Nwaoku, N.A., \& Tom, A. (2009). Nigeria's tertiary education curriculum in the $21^{\text {st }}$ century: The implications and challenges. Journal of curriculum organization of Nigeria. 3 (1\&2), 5-12.

[14]. Ratio Pty Ltd., \& Down, C. (2002). Employability skills in training packages. ANTA, Brisbane.

[15]. Boyle, E. A., Duffy, T., \& Dunleavy, K. (2003). Learning styles and academic outcome: The validity and utility of varmints inventory of learning style in a British higher education setting. British Journal of Educational Psychology 73 (2), $267-290$.

[16]. UNESCO (2002). Information and communication technology in teacher education. Retrieved on November 10, 2007, from http://www.unesdoc.ogr/images/0012/001295/129533epdf

[17]. Roegge, C. A., Wenting, T. L., \& Bragg, D. D. (1996). Using technical principles to improve teacher education. Journal of Vocational and Technical Education. 13 (1). Retrieved on October $10^{\text {th }}, 2007$ from http//:www.scholar/lib.vt.edu/ejournals/JVTE/V13NL/roegge.html.

[18]. Olaitan, S. O. (1996). Vocational and technical education: Issues and analysis. Onitsha: Noble Graphic Press.

[19]. Hobart, R. B. (1997). Training of teachers/trainers in technical and vocational education. Retrieved November 10, 2007, from http//:www.unevoc.unesco.ogrg/publications/studies/studies-11e

[20]. Karen, J. (2002). Managing small group learning. Newtown, NSW: Primary English Teaching Association (PETA).

[21]. Oviawe, J.I. Differential effects of three instructional methods on students academic performance in building technology in polytechnics. Unpublished Ph.D thesis, Department of Vocational Teacher Education, University of Nigeria, Nsukka. 2010

[22]. Smith, E. \& Kruger, J. (2008). A critical assessment of the perception of potential graduates regarding their generic skill level. An exploratory study. SAJEMS 11 (2), 121-130.

[23]. Bowman, K. (2009). Give us good generic skills. Campus Review (3)18. Retrieved January 30, 2009 from http://www.campusreview.com.au/pages/section/article.php?s=VET\&idArticle $=6620$

[24]. OFSTED (2007). Developing social, emotional and behavioural skills in secondary schools: A five-term longitudinal evaluation of the secondary national strategy pilot. London: OFSTED 